\title{
The effect of pozzolanic mineral additives on the strength and durability properties of structural lightweight concrete
}

\author{
Engin Yener ${ }^{*},{ }^{1}$, Ali Khanjarkhani ${ }^{2}$, Rüstem Gül ${ }^{1}$ \\ ${ }^{1}$ Department of Civil Engineering, Faculty of Engineering, Iğdır University, Turkey \\ ${ }^{2}$ Faculty of Engineering, Atatürk University, Turkey
}

\section{Keywords}

\section{Lightweight concrete}

Pavement materials,

Sulfuric acid,

Nitric acid,

Perlite,

Silica fume,

Fly ash,

Exhaust gases.

\begin{abstract}
Structural lightweight concretes have the potential to be used in road pavements and bridge decks due to their properties such as sufficient wear resistance, high impermeability, superior freeze-thaw resistance and ductile behavior. However, road pavements are directly exposed to nitric acid and sulfuric acid solutions created by the exhaust gases of transportation vehicles in humid environments. Therefore, the concrete to be used in road pavements must be resistant to these acid effects. In addition, sufficient strength must be guaranteed when used as pavement material. The aim of this study is to produce lightweight concrete suitable for road pavements and other structures exposed to acid effects. For this, the effect of silica fume (SF) and fly ash (FA) on acid resistance and strength development of lightweight concrete with perlite aggregates was investigated. Five different lightweight concrete mixtures were produced by substituting 0\%, $\%$ SF, 10\% SF, 10\%FA, 20\% FA instead of cement by weight. Natural perlite rock has been used as an aggregate source in order to provide high strength and lightness. The cylindrical samples produced were kept in lime saturated water cure for 120 days and their compressive strength was measured on the 28th, 56th, 90th and 120th days. In addition, in order to monitor the acid resistance, the strength changes of the samples exposed to $5 \%$ sulfuric acid and $5 \%$ nitric acid solution after 28 days of standard curing were followed until the 120th day. Results show that, SF and FA additives increase the compressive strength especially at older ages. In case of $10 \% \mathrm{SF}$, the 120-day strength value increased by $18.6 \%$ and reached $34.5 \mathrm{MPa}$. Also, lightweight perlite concrete is highly resistant to nitric acid and sulfuric acid effects. In the case of 92 days of nitric acid and sulfuric acid exposure, the strength losses are only $5.2 \%$ and $13.4 \%$, respectively. In order to fully benefit from SF and FA, concretes must be adequately cured before acid attack. It has been concluded that it is possible to produce high-strength and acid-resistant lightweight concretes suitable for road pavements and many other structural elements by using natural perlite aggregate.
\end{abstract}

\section{Introduction}

Concrete is the most widely used material in the construction industry due to the many advantages it provides. According to the data of 2019, the annual concrete production of the European Union countries is 260 million $\mathrm{m}^{3}$. Turkey with a total production value of 67 million $\mathrm{m}^{3} /$ year is the largest producer of concrete in Europe. In addition, $94.5 \%$ of the concrete produced in Turkey is of high quality (strength class C25/30 and higher)[1]. However, concrete used as a building material has aspects open to improvement. Especially conventional concrete, which has a high density, causes the loads of the structures to increase and as a result, the horizontal forces affecting the structure during an earthquake reach great values. This situation causes an increase in the dimensions of the structural elements and an increase in costs. In addition, the heat conduction and sound insulation properties of conventional concrete are insufficient. In case of using lightweight concrete, these problems can be avoided and economical, safe and comfortable structures can be designed. Also, the flexible behavior of lightweight concrete is a positive feature in terms of use in road and airport pavements. If it is used in the base course of pavement, it can better adapt to subbase and subgrade and will contribute positively to the load distribution by reducing the shock effect of the aircraft and other transportation vehicles.

In case the high strength and durability properties of lightweight concrete are guaranteed, it can be used for many engineering structural elements. Studies on this area show the importance of the subject [2-4].

Lightweight concrete production can be done in different ways depending on whether the voids are in the paste (foam concrete), between the aggregates (no-fine concrete) or in the aggregate (lightweight aggregate concrete). In order to achieve high strength, sound lightweight aggregates should be used [5]. Volcanic-origin aggregates such as pumice and perlite, industrial waste slag, plastic waste, etc. materials can be used as aggregates in structural lightweight concretes [6-9]. In this study, raw perlite aggregate was used in the production of structural lightweight concrete. Perlite is a sound lightweight rock with high silica content, amorphous structure and relatively high water content.

An important feature that will enable the expansion of the usage area of lightweight concrete to cover structures exposed to chemical effects is the improvement of its durability. For example, concrete road pavements, sewerage pipes, irrigation channels, buildings in industrial zones are exposed to acid effects. Concrete material used in such engineering structures may come into contact with sulfuric acid or nitric acid solutions, and in this case, concrete can be significantly damaged [10-12]. Strength losses of $30 \%$ and $40 \%$, respectively, were reported in conventional concretes exposed to the solutions of $5 \%$ nitric acid and $5 \%$ sulfuric acid for 60 days $[13,14]$. The lightweight concretes produced in this study is aimed to be more resistant than the conventional concretes. 
The harmful acids can come from various sources. For example, sulfur dioxide $\left(\mathrm{SO}_{2}\right)$ in the exhaust gases of transportation vehicles can turn into sulfuric acid in humid environments and cause acid damage in concrete road pavements [16]. Similarly, hydrogen sulfide gas $\left(\mathrm{H}_{2} \mathrm{~S}\right)$ released from waste water in sewage systems can be transformed into sulfuric acid by dissolving in the water film on the moist concrete surface and then combining with the oxygen in the air [17]. Also, some types of bacteria found in sulphated soils are also a cause of sulfuric acid formation $[18,19]$

The general negative effect of acids is related to the change in the $\mathrm{PH}$ level of concrete. The pore solution of concrete has a high $\mathrm{PH}$ level due to its $\mathrm{Ca}(\mathrm{OH})_{2}$ content. Generally, in concretes exposed to acid, the $\mathrm{PH}$ level in pore solution decreases and as a result, the hydration products that give the concrete its strength lose calcium and weaken [15]. If the sulfuric acid solution formed for any reason comes into contact with the concrete, it reacts with calcium hydroxide $(\mathrm{C}-\mathrm{H})$ and calcium-silica-hydrate (C-S-H) gels in the concrete and turns into gypsum $\left(\mathrm{CaSO}_{4} \cdot 2 \mathrm{H}_{2} \mathrm{O}\right)$. The gypsum formed then reacts with calciumalumina-hydrate in the concrete to form ettringite compound. As a result of the reaction, approximately five-fold increase in volume occurs[20]. This volume increase in the hardened concrete causes the concrete to break mechanically. The mechanism of gypsum formation with the effect of sulfuric acid can be formulated as follows [21, 22].

$\mathrm{Ca}(\mathrm{OH})_{2}+\mathrm{H}_{2} \mathrm{SO}_{4}->\mathrm{CaSO}_{4} \cdot 2 \mathrm{H}_{2} \mathrm{O}$

$3 \mathrm{CaO} .2 \mathrm{SiO}_{2} .3 \mathrm{H}_{2} \mathrm{O}+\mathrm{H}_{2} \mathrm{SO}_{4}->\mathrm{CaSO}_{4} \cdot 2 \mathrm{H}_{2} \mathrm{O}+\mathrm{Si}(\mathrm{OH})_{4}$

In addition, nitrogen dioxide gas $\left(\mathrm{NO}_{2}\right)$ released from the exhausts of transportation vehicles and industrial plant chimneys combines with water to form nitric acid $\left(\mathrm{HNO}_{3}\right)$ that damages concrete roads. $\mathrm{HNO}_{3}$, whose formation mechanism is given below, damages concrete by converting the $\mathrm{C}-\mathrm{H}$ component, a product of hydration, into calcium nitrate salt and calcium-nitra-alumina-hydrate [21, 22].

$3 \mathrm{NO}_{2}+\mathrm{H}_{2} \mathrm{O} \rightarrow 2 \mathrm{HNO}_{3}+\mathrm{NO}$

$2 \mathrm{HNO}_{3}+\mathrm{Ca}(\mathrm{OH})_{2}-\mathrm{Ca}(\mathrm{NO} 3) 2.2 \mathrm{H}_{2} \mathrm{O}$

$\mathrm{Ca}\left(\mathrm{NO}_{3}\right)_{2} \cdot 2 \mathrm{H}_{2} \mathrm{O}+3 \mathrm{CaO} . \mathrm{Al}_{2} \mathrm{O}_{3} \cdot 8 \mathrm{H}_{2} \mathrm{O}$

$->3 \mathrm{CaO} . \mathrm{Al}_{2} \mathrm{O}_{3} \cdot \mathrm{Ca}\left(\mathrm{NO}_{3}\right)_{2} \cdot 10 \mathrm{H}_{2} \mathrm{O}$

It is possible to use pozzolanic additives such as silica fume (SF) and fly ash (FA) to improve the durability properties of concrete [23, 24]. FA is obtained by grinding low-calorie coals very finely and keeping the ashes formed by burning them in thermal power plants in chimney filters. FA exhibits pozzolanic properties due to their amorphous structure, fineness and chemical content. SF, a gray powder, is obtained by reducing the ferrosilicon alloy of high purity quartzite in electric arc furnaces. The SiO gas released during the process combines with the oxygen in the air to form an amorphous finegrained SF. The fineness of SF is about a hundred times smaller than cement. FA and SF are pozzolanic mineral additives that exhibit binding properties when used in concrete with cement. These additives, which react with calcium hydroxide $(\mathrm{C}-\mathrm{H})$ formed as a result of cement hydration, form additional calcium silica hydrate (C-S-H) gels and improve the strength and durability of concrete. However, SF increases the water requirement of the concrete mixture due to its high fineness and can worsen the workability. Superplasticizer additives are used to avoid workability problems.

The contribution of pozzolanic minerals such as FA and SF, which are industrial waste or by-products, to the durability of normal aggregated concrete has been revealed in the literature [24]. According to the study of Monteny et al. (2003) despite the properties such as low air content, low water absorption rate and high density, silica fume has shown very low resistance to sulfuric acid effect for normal concretes[20]. However, in another study, the resistance of fly ash and silica fume against sodium sulphate solution was investigated and its positive effects were shown [25].

The aim of this study is to produce lightweight concrete suitable for structures such as road pavements exposed to acid effect. The study contains novelty in this aspect as there is limited work in this area. Perlite aggregate is used to provide sufficient strength and sufficient lightness together. Likewise, pozzolanic mineral additives (SF and FA) were used to improve the properties of the cement paste. Measurable targets for this purpose are to reach density values lower than $1850 \mathrm{~kg} / \mathrm{m}^{3}$ and compressive strength values higher than $17 \mathrm{MPa}$. In addition, in terms of acid resistance, it is aimed to stay below the $30 \%$ strength loss limit. In this context, the effect of FA and SF additive on acid resistance and strength development of lightweight concrete was investigated. It has been shown that lightweight concretes with high strength and resistant to sulfuric acid and nitric acids can be produced with perlite aggregate and pozzolanic additives.

\section{Materials and Methods}

CEMII/B 42.5R type Portland cement was used as the main binding material in the lightweight concrete mixtures prepared for the experimental study. The dosage of the binding material has been kept constant as $400 \mathrm{~kg} / \mathrm{m}^{3}$ for each mixture. Silica fume and fly ash were used as pozzolanic binding additives. Raw perlite from Erzincan in Turkey was used as coarse and fine aggregate. Properties of perlite aggregate, fly ash and silica fume are given in Table 1. The silica fume was obtained from the ferrosilicon factory of Eti Metalurji A.S in Antalya, Turkey. SF is a powder material with high silica content (95\% $\left.\mathrm{SiO}_{2}\right)$ and high fineness (20000 $\mathrm{m}^{2} / \mathrm{kg}$ specific surface area). In the study, SF was used at the replacement ratios of $0 \%, 5 \%$ and $10 \%$ by cement.

Table 1. Chemical and physical properties of perlite, FA and SF

\begin{tabular}{lllll}
\hline & PC & FA & SF & Perlite \\
\hline $\mathrm{SiO}_{2}$ & 20.56 & 42.14 & 94.6 & $71-75$ \\
$\mathrm{Al}_{2} \mathrm{O}_{3}$ & 5.01 & 19.38 & 0.5 & $12.5-16$ \\
$\mathrm{Fe}_{2} \mathrm{O}_{3}$ & 2.25 & 4.64 & 1 & $0.3-0.5$ \\
$\mathrm{CaO}$ & 56.38 & 26.96 & 1.4 & $0.4-0.82$ \\
$\mathrm{SO}_{3}$ & 2.28 & 2.43 & 0.21 & $0-0.2$ \\
$\mathrm{MgO}$ & 3.01 & 1.78 & & $0.02-0.03$ \\
$\mathrm{~K} 2 \mathrm{O}$ & 0.59 & 1.13 & & $4-5$ \\
$\mathrm{Na} 2 \mathrm{O}$ & 0.39 & & & 3.2 \\
$\mathrm{LOI}$ & 9.07 & 1.34 & & \\
$\mathrm{SG}\left(\mathrm{kg} / \mathrm{m}^{3}\right)$ & 2990 & 2180 & 2360 & \\
$\mathrm{SSA}\left(\mathrm{m}^{2} / \mathrm{kg}\right)$ & 440.6 & & 20000 & \\
\hline
\end{tabular}

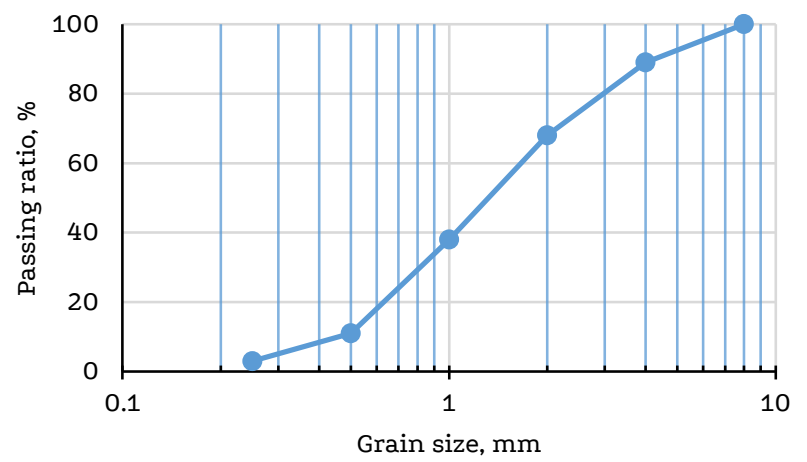

Figure 1. Gradation curve of perlite agregate, $\operatorname{Dmax}=8 \mathrm{~mm}$.

Fly ash obtained from the Orhaneli Thermal Power Plant was used as cement replacement ratios of $0 \%, 10 \%$ and $20 \%$. Polycarboxylic etherbased superplasticizer was used by adding $1.5 \%$ by weight of binder 
materials to the mixing water to eliminate the negative effects of high fineness mineral additives on workability. Maximum aggregate size of $8 \mathrm{~mm}$ was selected and aggregate clusters in three different size ranges were combined in calculated proportions in order to obtain a suitable granulometry. The combined gradation curve of the perlite aggregate is given in Figure 1.

Five different types of mixtures prepared in the laboratory environment were placed in cylinder molds of $15 \mathrm{~cm}$ diameter and 30 $\mathrm{cm}$ height, kept for one day, then removed from the mold and placed in the curing pool. The curing environment was water saturated with lime and its temperature was $23 \pm 2{ }^{\circ} \mathrm{C}$. Unit volume weights of the mixtures were determined after 28-day curing period. Compressive strength tests were conducted at 28,56, 90 and 120 days of standard curing. Also, a group of samples were transferred into $5 \%$ sulfuric acid $\left(\mathrm{H}_{2} \mathrm{SO}_{4}\right)$ and $5 \%$ nitric acid $\left(\mathrm{HNO}_{3}\right)$ solution after 28 days of standard curing. Similarly, the strength of these samples on the 28th, 56th, 90th and 120th days after the production was determined by compressive tests. Other details of materials and methods can be found elsewhere [26]

\section{Results and discussion}

\subsection{Unit volume weights}

28 days after the concrete mixes were produced, the densities of the samples were determined through experiments. As can be seen from the results given in Figure 2 and Figure 3 the density values of all mixtures remained below the lightweight density limits $\left(1850 \mathrm{~kg} / \mathrm{m}^{3}\right)$ specified in the standards. With the increase in the amount of mineral additives used, the dry densities of the samples also increased. This situation can be explained by the fact that fine mineral additives fill small gaps and form a denser binding paste. When the mixtures were compared, the $10 \%$ SF mixture had the highest density $\left(1810 \mathrm{~kg} / \mathrm{m}^{3}\right)$ and the control mixture without mineral additives had the lowest density value $\left(1780 \mathrm{~kg} / \mathrm{m}^{3}\right)$.

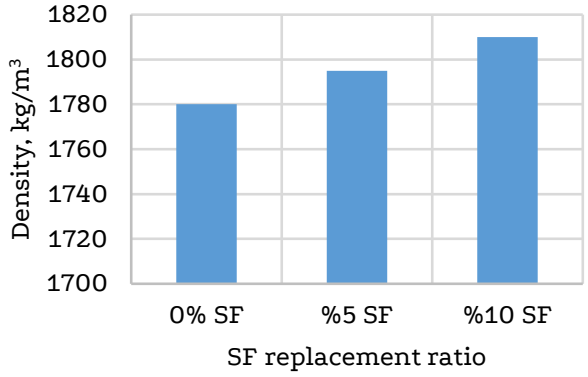

Figure 2. The effect of SF replacement ratio on the density of lightweight concrete

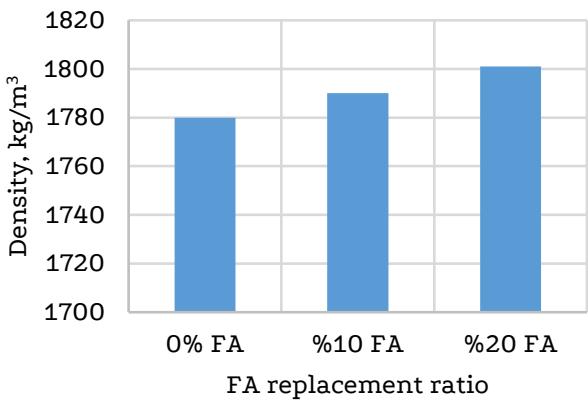

Figure 3. The effect of FA replacement ratio on the density of lightweight concrete
3.2

\section{Compressive strengths}

The change of compressive strength of perlite aggregate concrete without mineral additives and concrete with additives is graphically shown in Figure 4-5.

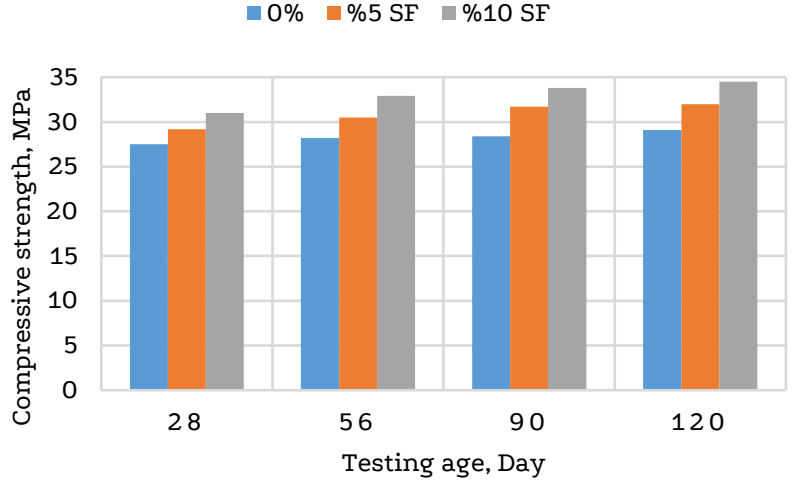

Figure 4. The effect of SF ratio on compressive strength development in standard water curing.

$\square \% \quad \% 10 \mathrm{FA} \quad \square 20 \mathrm{FA}$

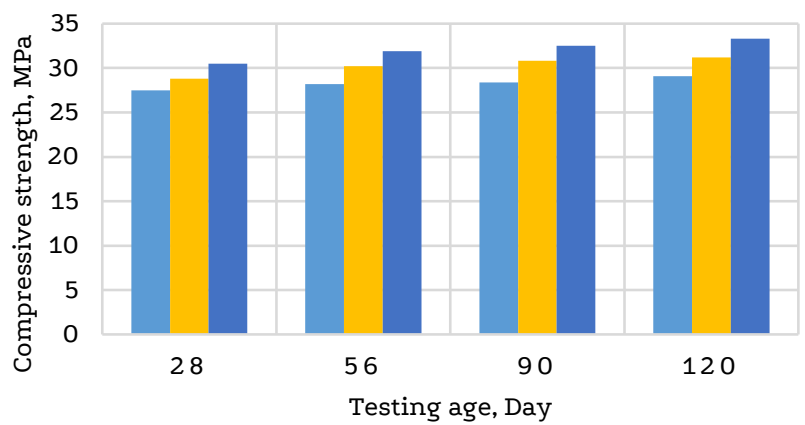

Figure 5. The effect of FA ratio on compressive strength development in standard water curing.

As can be seen, the mixture type with the highest 28-day compressive strength $(31 \mathrm{MPa})$ is mixture containing $10 \% \mathrm{SF}$. This is followed by mineral additive mixtures containing $20 \% \mathrm{FA}(30.5 \mathrm{MPa}), 5 \% \mathrm{SF}(29.2$ $\mathrm{MPa})$ and $10 \% \mathrm{FA}(28.8 \mathrm{MPa})$, respectively. The additive-free control sample exhibited the lowest 28-day compressive strength (27.5 $\mathrm{MPa})$. The use of SF and FA additives has provided an increase in strength at all times. The $10 \%$ cement replacement ratio of SF increased the 28 day strength of concrete by $12.7 \%$ compared to the control mix. When the knowledge in the literature are evaluated, the use of SF and FA in mixtures with normal weight aggregate types increases the strength [23]. Similar strength increase was observed in this study using perlite aggregate.

As is known, the strength gain continues over time depending on the hydration reactions. However, strength gain slows down after 28 days in normal concretes. In this study, the strength increase in the mixtures produced by using mineral additives continued significantly after 28 days due to the pozzolanic reactions. The strength gap between $10 \%$ SF mixture and the control mixture has increased up to $18.6 \%$ (at $120^{\text {th }}$ day) from $12.7 \%$ (at $28^{\text {th }}$ day), over time. A long-term, stable and continuous strength gain has been achieved with the use of SF and FA mineral additives. The 28day strength values of all lightweight concretes produced with perlite aggregate have exceeded the strength limit of structural concretes (>17 MPa) [27]. This situation shows that raw perlite can be used in production of structural lightweight concretes. 


\subsection{Resistance to acid attack}

The strength development of the concrete samples left in the $5 \%$ nitric acid solution after 28 days of water curing is shown in Figure 6-7. While a significant increase in strength is expected under normal curing conditions, there is a slight increase until the 90th day and then a decrease in strength due to the acid effect. The reason for this is that while hydration reactions and pozzolanic reactions in concrete continue to contribute to the strength gain, acid damage from the surface has a weakening effect on the concrete. However, the decrease in strength due to the acid effect remained small. The 120-day strength of concrete without admixture, which was $29.1 \mathrm{MPa}$ in normal water curing condition (Fig.4), decreased to $27.6 \mathrm{MPa}$ with nitric acid effect (Fig.6). In this case, the loss in strength remained at $5.2 \%$. Taku et al. (2015) stated in their study that the strength of normal concretes exposed to $5 \%$ nitric acid solution for 60 days decreased by $30 \%[14]$. When the strength of the lightweight concrete produced with perlite aggregate in this study is compared with the results in the literature, it can be concluded that lightweight concrete with perlite aggregate is more resistant to nitric acid attack than normal concretes.

The strength loss at 120-day strengths due to the effect of nitric acid was $5.2 \%, 7.1 \%, 7.8 \%, 8.1 \%$ and $9.3 \%$ for the additive-free mixture and $10 \% \mathrm{FA}, 20 \% \mathrm{FA}, 5 \% \mathrm{SF}, 10 \% \mathrm{SF}$, respectively. The results show that the additive-free mixtures are more resistant to acid effect and the higher the additive ratio, the higher the strength loss caused by the acid effect. Here, while determining the strength loss ratios, the 120day strength values (Fig.4) reached in the case of water curing (Fig.4) and the strengths of the samples exposed to acid after 28 days (Fig.6) were compared.

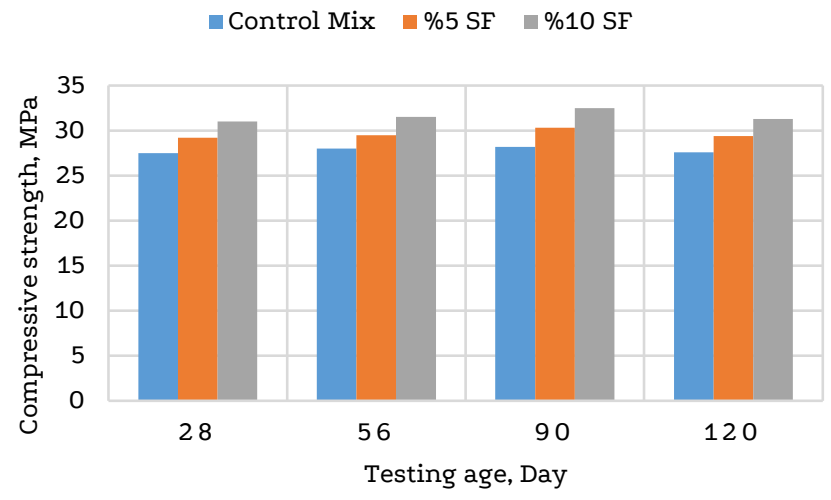

Figure 6. The effect of SF ratio on strength development in nitric acid $\left(5 \% \mathrm{HNO}_{3}\right)$ solution

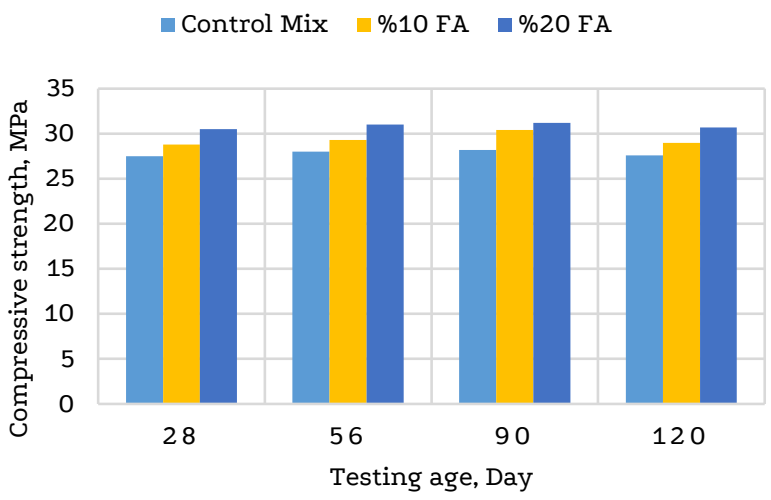

Figure 7. The effect of FA ratio on strength development in nitric acid $\left(5 \% \mathrm{HNO}_{3}\right)$ solution
It can be seen from Figure 8-9 that the strength of the samples left in the sulfuric acid solution has increased slightly up to 90 days. It can be said that acid damage remained at a superficial level until the 90th day and the hydration reactions continuing in the interior of the samples increased the strength slightly. This situation shows that the sulfuric acid attack starts on the surface and then affects the concrete as stated in previous studies (Kong et al., 1987; Attiogbe and Rizkalla, 1988)[15, 28]. As can be seen in Figure 8-9, the strengths decreased significantly after the 90th day (62 days of acid effect). After this stage, it can be concluded that sulfuric acid, which reaches to the voids in the concrete, forms gypsum and ettringite with the reactions described above and the resulting volume increase damages the concrete (Baradan et al., 2010; Zivica, 2001)[21, 22].

While the strength value of the control mixture cured under normal conditions reached $29.1 \mathrm{MPa}$ in 120 days (Fig.4), it remained at the value of $25.2 \mathrm{MPa}$ (Fig.8) in the case of curing in sulfuric acid solution. Thus, the strength loss of perlite concrete without mineral additives after 92 days $5 \% \mathrm{H}_{2} \mathrm{SO}_{4}$ solution effect was realized at the level of $13.4 \%$. According to the studies in the literature, it can be concluded that concrete with perlite aggregate is more resistant to sulfuric acid compared to normal concretes when it is considered that normal concretes exposed to $5 \%$ sulfuric acid for 60 days have a strength loss of $40 \%$ [13].

The strength loss occurred at 120-day strengths due to the effect of sulfuric acid was $13.4 \%, 15.1 \%, 12.9 \%, 14.1 \%, 13.3 \%$ for additive-free mixture and the mixtures with $10 \% \mathrm{FA}, 20 \% \mathrm{FA}, 5 \% \mathrm{SF}, 10 \% \mathrm{SF}$ respectively. As can be seen, the strength losses occurring with long term sulfuric acid effect (92day) are close to each other. In this case, it can be concluded that mineral additives do not provide a positive contribution in terms of sulfuric acid resistance. The reason why SF and FA additives do not benefit acid resistance can be attributed to their exposure to acid after a short curing period (28 days), which does not allow pozzolanic reactions to complete. Because pozzolanic reactions occur with the $\mathrm{C}-\mathrm{H}$ released as a result of the cement hydration reaction and take place in the long term. As a matter of fact, the effect of pozzolanic effects on long-term strength is seen in the high strength values obtained in the case of 120-day water cure.

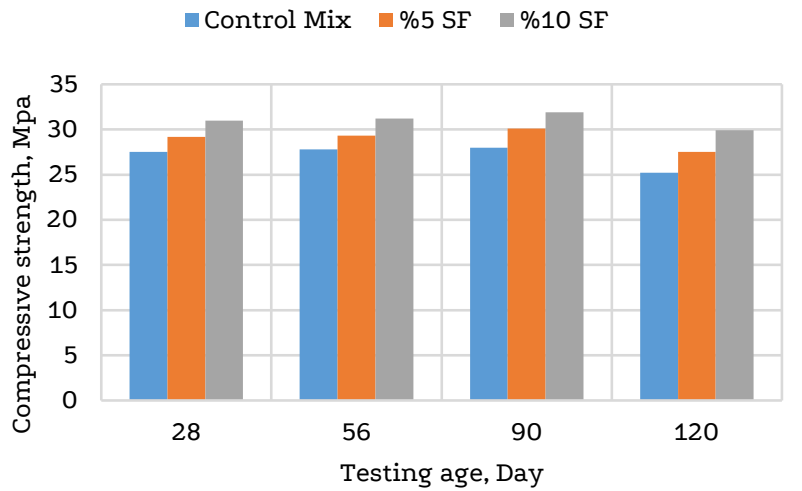

Figure 8. The effect of SF ratio on strength development in sulfuric acid $\left(5 \% \mathrm{H}_{2} \mathrm{SO}_{4}\right)$ solution 


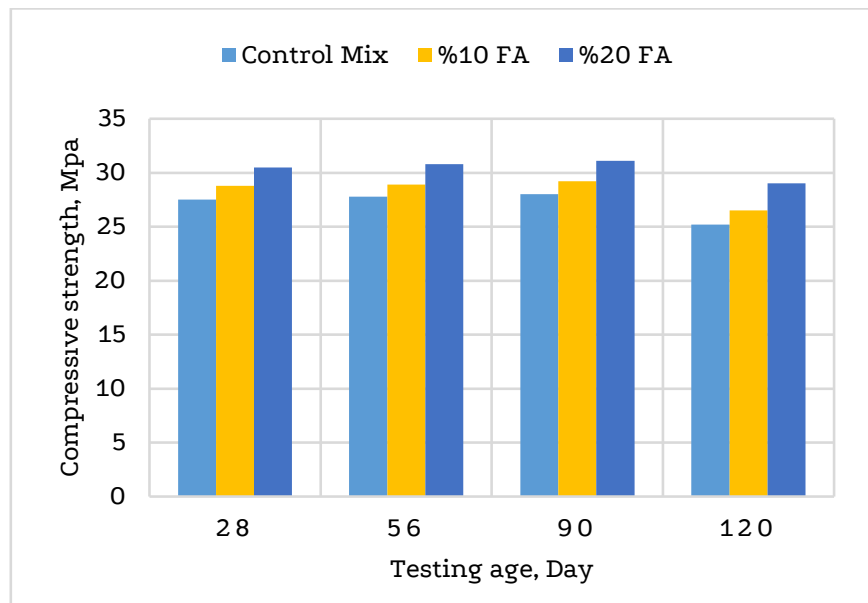

Figure 9. The effect of FA ratio on strength development in sulfuric acid $\left(5 \% \mathrm{H}_{2} \mathrm{SO}_{4}\right)$ solution

The contribution of perlite aggregate to acid resistance can be explained by the improvement of aggregate-paste interface properties. Interfacial transition zone (ITZ) is the weakest phase that negatively affects the strength and durability properties in conventional concretes. For normal aggregate concretes, the large difference between the stiffness of the aggregate and the paste phase causes the formation of micro-cracks at the interfacial transition zone (ITZ). In addition, water accumulating on the unabsorbent aggregate surface (wall effect) in normal concretes increases the w/cm ratio in ITZ. Therefore, the paste phase at the interface shrinks too much and eventually forms micro-cracks. and causes a weak porous ITZ with micro-cracks [29]. In lightweight aggregate concrete, the stiffness difference between aggregate and paste is lower. So, micro-crack formation due to stiffness difference is less. Also, porous lightweight perlite aggregate allows excess water on the surface to enter the aggregate and prevents the increase of $\mathrm{w} / \mathrm{cm}$ ratio in the ITZ [30]. In addition, the water taken into the aggregate has an internal curing effect for the reactions at the interface zone [27]. Thus, the strength and acid resistance of the concretes using perlite aggregate were high.

\section{Conclusions}

In this study, it has been shown that lightweight concretes with high strength and resistant to acidic environments. High compressive strength and acid resistance with sufficient lightness have been achieved economically by using raw perlite aggregate. Silica fume and fly ash improved the cement paste properties and increased the strength under normal curing conditions. It was concluded that improvements in the interfacial transition zone were the source of the benefits achieved. The findings obtained in the study are summarized below.

- If perlite aggregate is used in its raw form without expanding, it is possible to produce structural lightweight concrete.

- The mixture, using $100 \%$ raw perlite aggregate and not using pozzolanic mineral additives, had the lowest unit volume weight of $1780 \mathrm{~kg} / \mathrm{m}^{3}$.

- As the cement replacement ratio of mineral additives (FA and SF) increased, the densities also slightly increased. The highest density value $\left(1810 \mathrm{~kg} / \mathrm{m}^{3}\right)$ was measured in the mixture containing $10 \% \mathrm{SF}$.

- SF and FA additives increase the compressive strength. In case of $10 \% \mathrm{SF}$, the 120 -day strength value increased by $18.6 \%$ and reached $34.5 \mathrm{MPa}$.

- SF and FA continued to contribute to strength in older ages up to 120th day.

- Lightweight concrete with perlite aggregate is highly resistant to nitric acid and sulfuric acid effects. The strength loss was $5.2 \%$ and
$13.4 \%$ for nitric acid and sulfuric acid exposure of 92 days, respectively.

- It has been determined that sulfuric acid effect is more detrimental than nitric acid for concretes.

- SF and FA additives were not beneficial in concretes exposed to acid before pozzolanic reactions were completed. In order to fully benefit from pozzolanic additives, concretes must be adequately cured before acid attack.

- The fact that a much better interface bond has occurred between the perlite aggregate and the cement paste compared to normal concrete, which has improved the resistance to acid attack.

\section{Declaration of Conflict of Interests}

The authors declare that there is no conflict of interest. They have no known competing financial interests or personal relationships that could have appeared to influence the work reported in this paper.

\section{References}

[1.] İstatistikleri, Y.H.B.S., Türkiye Hazır Beton Birliği. 2019.

[2.] Mishutn, A., et al., Modified expanded clay lightweight concretes for thin-walled reinforced concrete floating structures. Tehnički glasnik, 2017. 11(3): p. 121-124.

[3.] Tajra, F., et al., Properties of lightweight concrete made with coreshell structured lightweight aggregate. Construction and Building Materials, 2019. 205: p. 39-51.

[4.] Zhou, H. and A.L. Brooks, Thermal and mechanical properties of structural lightweight concrete containing lightweight aggregates and fly-ash cenospheres. Construction and Building Materials, 2019. 198: p. 512-526.

[5.] Rumsys, D., et al., Compressive strength and durability properties of structural lightweight concrete with fine expanded glass and/or clay aggregates. Materials, 2018. 11(12): p. 2434.

[6.] Ibrahim, M., et al., Durability of Structural Lightweight Concrete Containing Expanded Perlite Aggregate. International Journal of Concrete Structures and Materials, 2020. 14(1): p. 1-15.

[7.] Jaskulski, R. and W. Kubissa. Lightweight concrete with copper slag waste as sand substitution. in MATEC Web of Conferences. 2018. EDP Sciences.

[8.] Karaburc, S.N., S.A. Yildizel, and G. Calis, Evaluation of the basalt fiber reinforced pumice lightweight concrete. Magazine of Civil Engineering, 2020. 94(2).

[9.] Záleská, M., et al., Structural, mechanical and hygrothermal properties of lightweight concrete based on the application of waste plastics. Construction and Building Materials, 2018. 180: p. 1-11.

[10.] Barbhuiya, S. and D. Kumala, Behaviour of a sustainable concrete in acidic environment. Sustainability, 2017. 9(9): p. 1556.

[11.] Mehta, A. and R. Siddique, Sulfuric acid resistance of fly ash based geopolymer concrete. Construction and Building Materials, 2017. 146: p. 136-143.

[12.] Xie, Y., et al., Comparison of corrosion resistance mechanism between ordinary Portland concrete and alkali-activated concrete subjected to biogenic sulfuric acid attack. Construction and Building Materials, 2019. 228: p. 117071.

[13.] Aydin, S., et al., Sulfuric acid resistance of high-volume fly ash concrete. Building and Environment, 2007. 42(2): p. 717-721.

[14.] Taku, K.J., D.Y. Amartey, and T. Kassar, Effect of acidic curing environment on the strength and durability of concrete. equilibrium, 2015. 7(12).

[15.] Attiogbe, E.K. and S.H. Rizkalla, Response of concrete to sulfuric acid attack. ACI materials journal, 1988. 85(6): p. 481-488.

[16.] Fatima, F., et al., 5. A review on acid rain: An environmental threat. Pure and Applied Biology (PAB), 2020. 10(1): p. 301-310.

[17.] Chang, H.B. and Y.C. Choi, Accelerated performance evaluation of repair mortars for concrete sewer pipes subjected to sulfuric acid attack. Journal of Materials Research and Technology, 2020. 9(6): p. 13635-13645.

[18.] Sand, W. and E. Bock, Biodeterioration of mineral materials by microorganisms-biogenic sulfuric and nitric acid corrosion of concrete and natural stone. Geomicrobiology Journal, 1991. 9(23): p. 129-138. 
[19.] Usharani, K., D. Naik, And R. Manjunatha, Sulphur Oxidizing Bacteria: Oxidation, Mechanism and Uses-A Review.

[20.] Monteny, J., N. De Belie, and L. Taerwe, Resistance of different types of concrete mixtures to sulfuric acid. Materials and structures, 2003. 36(4): p. 242-249.

[21.] Baradan, B., H. Yazici, and H. Ün, Beton ve Betonarme Yapılarda Kalıcılık (Durabilite). Türkiye Hazır Beton Birliği Yayınları, İstanbul, 2010.

[22.] Zivica, V.r. and A. Bajza, Acidic attack of cement based materialsa review.: Part 1. Principle of acidic attack. Construction and Building materials, 2001. 15(8): p. 331-340.

[23.] Yener, E. and S. Hinislioğlu, The effects of silica fume and fly ash on the scaling resistance and flexural strength of pavement concretes. Road materials and pavement design, 2011. 12(1): p. 177-194.

[24.] Wang, D., et al., Durability of concrete containing fly ash and silica fume against combined freezing-thawing and sulfate attack. Construction and Building Materials, 2017. 147: p. 398406.

[25.] Bingöl, A.F. and H.H. Balaneji, Determination of sulfate resistance of concretes containing silica fume and fly ash. Iranian Journal of Science and Technology, Transactions of Civil Engineering, 2019. 43(1): p. 219-230.
[26.] Khanjarkhanı, A., Ham Perlit Agregası İle Üretilen Hafif Betonun Asitlere Karşı Dayanıklılığı. 2014, Yüksek Lisans Tezi, Atatürk Üniversitesi, Fen Bilimleri Enstitüsü.

[27.] Akers, D.J., et al., Guide for structural lightweight-aggregate concrete. ACI 213R-03. American Concrete Institute (ACI) Michigan, 2003.

[28.] Kong, H.L. and J.G. Orbison, Concrete deterioration due to acid precipitation. Materials Journal, 1987. 84(2): p. 110-116.

[29.] Golewski, G. L. (2019). The influence of microcrack width on the mechanical parameters in concrete with the addition of fly ash: Consideration of technological and ecological benefits. Construction and Building Materials, 197, 849-861.

[30.] Yoon, J. Y., \& Kim, J. H. (2019). Mechanical properties of preplaced lightweight aggregates concrete. Construction and Building Materials, 216, 440-449.

\section{How to Cite This Article}

Yener, E., Khanjarkhani, A., Gül, R., The effect of pozzolanic mineral additives on the strength and durability properties of structural lightweight concrete, Civil Engineering Beyond Limits, 2(2021), 25-61. https://doi.org/10.36937/cebel.2021.002.005 